\title{
PKM (PROGRAM KEMITRAAN MASYARAKAT) \\ PENGEMBANGAN KARAKTER PAUD DI DESA MUNTE KABUPATEN MINAHASA UTARA
}

\author{
Ni Dewi Eka Suwaryaningrat \\ Universitas Negeri Manado \\ nidewiekha@unima.ac.id
}

\begin{abstract}
Abstrak
Pendidikan untuk anak usia dini memegang peranan sangat penting pada pembentukan generasi penerus bangsa Indonesia di masa depan. Anak-anak usia dini merupakan bagian dari sumber daya manusia yang memerlukan penanganan yang serius dan berkelanjutan oleh semua pihak yang mempunyai tanggung jawab bersama pada pembentukan generasi penerus yang berkualitas. Untuk memastikan keberhasilan mendapatkan generasi penerus yang berkualitas ini maka diperlukan tindakan-tindakan nyata oleh pihak yang bergerak aktif dalam dunia pendidikan.

Tujuan dari pengabdian ini adalah: Publikasi ilmiah di jurnal/prosiding, Pemahaman dalam pengembangan karakter anak PAUD dan Model parenting dalam pengembangan karakter anak PAUD, menggunakan metode, pembimbingan sosialisasi dan dihasilkan bahwa Terselenggaranya Terselenggaranya sosialisasi program dengan pihak terkait dan terciptanya metode pengembangan karakter bagi anak PAUD, peserta dalam mengikuti pelatihan sangat antusias mengikuti pembelajaran menyenangkan, mempraktikkan metode-metode permainan yang membantu pengembangan karakter anak serta mendampingi lembaga PAUD sebagai peserta training pengembangan karakter anak PAUD.
\end{abstract}

Kata kunci: PAUD, Karakter, Sosialisasi

\section{PENDAHULUAN}

\section{Analisis Situasi}

Pendidikan untuk anak usia dini memegang peranan sangat penting pada pembentukan generasi penerus bangsa Indonesia di masa depan. Anak-anak usia dini merupakan bagian dari sumber daya manusia yang memerlukan penanganan yang serius dan berkelanjutan oleh semua pihak yang mempunyai tanggung jawab bersama pada pembentukan generasi penerus yang berkualitas. Untuk memastikan keberhasilan mendapatkan generasi penerus yang berkualitas ini maka diperlukan tindakan-tindakan nyata oleh pihak yang bergerak aktif dalam dunia pendidikan.
Berpijak dari kenyataan tersebut, pendidikan karakter merupakan hal yang penting dan porsinya harus dapat mengimbangi pendidikan intelektual dalam proses pendidikan, terlebih lagi pendidikan anak usia dini. Bagi anak usia dini, porsi pedidikan karakter idealnya lebih besar dari pendidikan intelektual (kognitifnya). Grafik yang dikembangkan oleh Marzano menggambarkan bahwa sikap/ karakter memegang porsi paling besar untuk menjadi sasaran kompetensi yang harus dimiliki AUD. Dalam grafik tersebut, ada 3 komponen kompetensi yang perlu dimiliki peserta didik, yakni sikap, pengetahuan, dan ketrampilan [1]. Pada jenjang PAUD, porsi kompetensi terbesar yang diharapkan 
adalah kompetensi sikap, diikuti kompetensi ketrampilan, dan baru selanjutnya kompetensi pengetahuan [2]. Semakin tinggi jenjang, sasaran kompetensi akan berbanding terbalik, hingga akhirnya pada jenjang perguruan tinggi, kompetensi pengetahuan diharapkan memegang porsi terbesar untuk kompetensi peserta didik [3].

Pendidikan anak usia dini (PAUD) adalah jenjang pendidikan sebelum jenjang pendidikan dasar yang merupakan suatu upaya pembinaan yang ditujukan bagi anak sejak lahir sampai dengan usia enam tahun yang dilakukan melalui pemberian rangsangan pendidikan untuk membantu pertumbuhan dan perkembangan jasmani dan rohani agar anak memiliki kesiapan dalam memasuki pendidikan lebih lanjut, yang diselenggarakan pada jalur formal, nonformal, dan informal [4].

\section{Komposisi Kompetensi pada Tiap Jenjang}

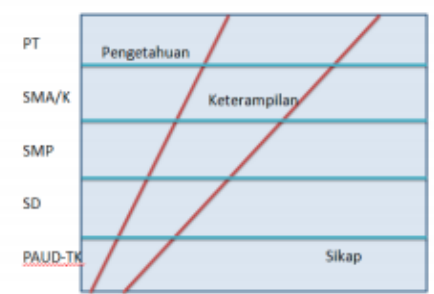

Gambar 1.1 Komposisi kompetensi dalam jenjang Pendidikan

Namun kenyataannya, ada orang tua yang belum menyadari peran pentingnya sebagai rekan aktif lembaga PAUD dalam pendidikan karakter bagi anak usia dini. Ada orang tua yang menganggap bahwa tanggung jawab pengajaran terbesar ada pada guru. Salah satu alasannya adalah karena guru dianggap memiliki ilmu yang memadai tentang bagaimana mengajar dan mendidik anak-anak mereka.

Oleh karena itu, lembaga PAUD, dalam hal ini sekolah, perlu mengajak orang tua untuk aktif berperan serta dalam mengajar dan mendidik anak-anak mereka. Alasan bahwa orang tua memiliki ilmu yang terbatas tentang bagaimana mengajar dan mendidik anak usia dini, dapat disiasati dengan kegiatan parenting. Kegiatan parenting yang dimaksud adalah kegiatan mengumpulkan orang tua siswa untuk kemudian mengadakan transfer ilmu pengetahuan. Pihak sekolah, yang dalam hal ini dianggap memiliki pengetahuan lebih tentang ilmu perkembangan anak dan kurikulum pendidikan, berperan menjadi si penyampai pengetahuan dan pihak orang tua berperan sebagai penerima pengetahuan. Melalui kegiatan parenting, pendidik AUD (guru), yang dalam hal ini dianggap memiliki ilmu pedagogik yang memadai, dapat membagi ilmu pedagogik yang dimilikinya kepada orang tua. Lembaga AUD yang kesehariannya berinteraksi dengan AUD yang bersangkutan lebih memiliki gambaran dalam memilih topiktopik parenting yang sesuai dengan kebutuhan komunitasnya sehingga akan lebih tepat sasaran. 
Selanjutnya, meskipun kegiatan parenting dianggap dapat menjadi solusi bagi masalah di atas, kegiatan parenting tersebut dalam penyelenggaraanya terkadang dirasa kurang optimal. Beberapa kegiatan parenting yang ada selama ini, biasanya menempatkan orang tua sebagai pendengar pasif, meskipun di akhir materi ada diskusi atau tanya jawab singkat. Kegiatan parenting yang demikian dikhawatirkan akan membuat orang tua jenuh, tidak sepenuhnya memahami materi yang disampaikan, kurang mampu mengaitkan teori dengan kenyataan yang terjadi, dan pada akhirnya berkurang motivasinya untuk menghadiri program parenting. Oleh karena itu, mengingat pentingnya kegiatan parenting sebagai saran komunikasi, mencari solusi, dan sharing ilmu pengetahuan terkait pendidikan Anak Usia Dini, kegiatan parenting tersebut perlu dibuat sekreatif mungkin supaya tidak membosankan.

\section{Permasalahan Mitra}

Berdasarkan analisis situasi di atas, dapat diidentifikasi permasalahan yang dihadapi mitra adalah sebagai berikut :

1. Peran orang tua dirasa masih kurang mendukung peran sekolah dalam hal pendidikan karakter anak usia dini

2. Metode kegiatan parenting yang selama ini ada biasanya membosankan karena kurang mengajak orang tua berperan aktif selama kegiatan tersebut

\section{TARGET DAN LUARAN}

Luaran Dan Target Capaian

Rencana Luaran

Adapun target luaran yang dijanjikan melalui program PKM ini adalah sebagai berikut:

1. Publikasi ilmiah di jurnal/prosiding: published

2. Pemahaman dalam pengembangan karakter anak PAUD

3. Model parenting dalam pengembangan karakter anak PAUD

\section{Solusi yang di tawarkan}

Uraian solusi yang dilaksanakan guna pemecahan masalah yang dihadapi mitra yakni:

1. Mengidentifikasi kebutuhan lembaga PAUD.

2. Menawarkan pemecahan permasalahan dengan mengadakan program workshop pengembangan karakter pada anak usia dini. Kegiatan workshop ini diharapkan dapat meningkatkan pengetahuan dan keterampilan tenaga pendidik sekolah mitra.

3. Menyusun materi yang telah ditetapkan kedalam handout dan media pembelajaran. 
4. Memberikan workshop

5. Mengevaluasi dan merefleksi kegiatan pelatihan dengan menggunakan lembar observasi dan kuesioner.

\section{METODE PELAKSANAAN}

\section{Metode Pelaksanaan}

Dalam upaya mengatasi kesulitan yang dialami mitra, maka ada beberapa solusi yang ditawarkan yaitu :

a. Melaksanakan program pelatihan dengan menjalankan rangkaian aktivitas untuk meningkatkan kompetensi guru dalam pengembangan karakter PAUD.

b. Memberikan pelatihan pembuatan bahan pembelajaran yang menarik dan interaktif disertai audio visual ketika diberikan kepada anak-anak.

c. Melakukan pendampingan kepada para guru pengelola lembaga PAUD untuk menyusun dan merancang prosedur metode pembelajaran yang dapat mengembangkan karakter PAUD guna memperbaiki kualitas pengelolaan proses pembelajaran serta pengembangan anak usia dini.

d. Melaksanakan sosialiasi tentang peran aktif orang tua dan lembaga pemerintah desa melalui kegiatan pertemuan dengan para orang tua anak dan pimpinan pemerintahan desa serta tokoh masyarakat adat di wilayah seputar lembaga PAUD.
Materi yang disampaikan dalam sosialisasi adalah berkaitan dengan sampai sejauh mana orang tua anak dapat ikut berperan untuk melaksanakan pengembangan karakter pada PAUD yang berbasiskan keluarga dan peranan apa saja yang dapat diberikan oleh lembaga pemerintahan desa . Sosialisasi dirancang dalam waktu 1 (satu hari). Melalui sosialisasi tersebut, para orang tua anak diberikan pembekalan bagaimana menerapkan PAUD di dalam keluarga masing-masing sehingga dapat membantu memudahkan orang tua untuk ikut aktif mengembangkan potensi dan bakat anaknya. Setelah melakukan seminar, kegiatan selanjutnya akan diselenggarakan workshop (pelatihan) kepada para pengelola dan pendidik di lembaga PAUD untuk mampu membuat Alat Permainan Edukatif (APE) yang menggunakan sumber daya alam di sekitar lembaga PAUD . Kegiatan berikutnya masih dalam bentuk workshop dengan merancang dan membuat materi bahan pembelajaran yang interaktif dengan keunggulan audio visual menggunakan sarana multi media di lembaga PAUD dan di perguruan tinggi. Workshop dirancang dilaksanakan masingmasing selama dua hari. Setelah melakukan rangkaian kegiatan sosialisasi dan workshop, untuk memastikan kualitas hasil karya yang dihasilkan, maka dilanjutkan dengan proses pendampingan. Pendampingan dilaksanakan melalui bimbingan face to face secara berkelanjutan sampai dihasilkan produk berupa Alat 
Permainan Edukatif (APE), materi multimedia pembelajaran anak di PAUD, proposal kerjasama dengan lembaga lain, dan dokumen prosedur operasi standar manajemen lembaga PAUD.

a. Metode diskusi

Proses interaksi antara dua atau lebih individu yang terlibat, saling tukar menukar pengalaman, informasi, memecahkan masalah, dapat terjadi juga semuanya aktif tidak ada yang pasif sebagai pendengar saja. Menggunakan metode diskusi berarti :

1) Dibagi dalam beberapa kelompok

2) Dapat mempertinggi kegiatan sebagai keseluruhan dan kesatuan

3) Dapat mempertinggi partisipasi secara individual

4) Rasa sosial dapat dikembangkan, karena bisa saling membantu dalam memecahkan masalah, mendorong rasa kesatuan

5) Memberi kemungkinan untuk saling mengemukakan pendapat

6) Merupakan pendekatan yang demokratis

7) Memperluas pandangan

8) Menghayati kepemimpinan bersamasama

9) Membantu mengembangkan kepemimpinan b. Metode diskusi dilaksanakan sepanjang proses pendampingan berlangsung. Diskusi berlangsung dari multi arah, yakni antar peserta dengan peserta dan juga antara peserta denga pemberi materi pelatihan. Diharapkan dalam proses ini, permasalahan yang ditemukan dalam pelaksanaan pembelajaran disekolah minggu dapat terselesaikan.

c. Metode Lokakarya / Workshop

Lokakarya (Inggris: workshop) adalah suatu acara di mana beberapa orang berkumpul untuk memecahkan masalah tertentu dan mencari solusinya. Sebuah lokakarya adalah pertemuan ilmiah yang kecil. Sekelompok orang yang memiliki perhatian yang sama berkumpul bersama di bawah kepemimpinan beberapa orang ahli untuk menggali satu atau beberapa aspek khusus suatu topik. Sub-sub kelompok dibentuk untuk tujuan mendengarkan ceramahceramah, melihat demonstrasidemonstrasi, mendiskusikan berbagai aspek topik, mempelajari, mengerjakan, mempraktekkan, dan mengevaluasinya.

Sebuah workshop biasanya terdiri atas pimpinan workshop, anggota, dan narasumber. Metode lokakarya atau workshop dilakukan untuk memberikan bekal keterampilan pada peserta pendampingan mengenai cara membuat dan menggunakan Alat Permainan Edukatif (APE). Sehingga dapat digunakan oleh para 
peserta dalam menyelenggarakan pembelajaran pada sekolah minggu.

d. Rancangan Evaluasi

$$
\text { Evaluasi pelaksanaan }
$$

program pengabdian dilakukan untuk mengetahui tingkat keberhasilan pelaksanaan program pengabdian masyarakat. Berdasarkan perencanaan tindakan, keberhasilan pelaksanaan Program Kemitraan Masyarakt yang dilakukan berupa kegiatan diskusi dan workshop, maka aspek yang dievaluasi serta teknik yang digunakan untuk mengevaluasi pelaksanaan program dapat diamati pada Tabel 2 berikut :

Tabel 2 Teknik Evaluasi Pelaksanaan Program

\begin{tabular}{|c|c|c|}
\hline \multicolumn{2}{|r|}{ Aspek yang dievaluasi } & $\begin{array}{l}\text { Teknik } \\
\text { evaluasi }\end{array}$ \\
\hline a. & $\begin{array}{l}\text { Minat dan antusiasme } \\
\text { peserta selama worksop }\end{array}$ & \\
\hline b. & $\begin{array}{lr}\text { Ketercapaian } & \text { tujuan } \\
\text { program, } & \text { yakni } \\
\text { peningkatan kemampuan } \\
\text { mitra dalam melakukan } \\
\text { pengembangan program } \\
\text { pembelajaran anak-usia } \\
\text { dini }\end{array}$ & $\begin{array}{l}\text { Observasi dan } \\
\text { kuesioner }\end{array}$ \\
\hline & $\begin{array}{l}\text { Manfaat yang diperoleh } \\
\text { peserta dan lembaga }\end{array}$ & \\
\hline
\end{tabular}

Kriteria keberhasilan dalam program kemitraan masyarakat ini adalah jika terjadi peningkatan kemampuan peserta dalam mengembangkan pembelajaran anak usia dini, yang ditandai dengan respon dan tanggapan yang diberikan oleh peserta. e. Partisipasi Mitra dalam Pelaksanaan Program

Program pengabdian masyarakat ini dilaksanakan dengan dukungan dan peran serta mitra diantaranya adalah :

a. Menjadi sumber informasi dalam mendeskripsikan masalah dan kebutuhan yang dialami di lapangan dalam peyelenggaraan pendidikan anak usia dini.

b. Menjadi mediator bagi pemangku kepentingan, pelaksana pengabdian masyarakat, dan peserta pelatihan

\section{HASIL DAN PEMBAHASAN}

\section{Hasil Kegiatan}

Terselenggaranya sosialisasi program dengan pihak terkait dan terciptanya metode pengembangan karakter bagi anak PAUD. Sosialisasi ini penting dilakukan untuk menjelaskan maksud dan tujuan dari kegiatan yang akan dilakukan kepada sasaran, agar saat pelaksanaan kegiatan tidak ada pertanyaan dari phak pihak tertentu dan yang paling utama harapannya dapat berpartisipasi aktif selama kegiatan berlangsung pasca diselenggarakannya sosialisasi program dengan pihak terkait.

Selama pelatihan, peserta dalam mengikuti pelatihan sangat antusias mengikuti pembelajaran menyenangkan, mempraktikkan metode-metode permainan yang membantu pengembangan karakter anak. Dari pelatihan-pelatihan itu ada 
beberapa temuan yang didapat sebagai berikut :

1. Kegiatan pelatihan dapat terlaksana sesuai jadwal yang ditentukan

2. Hampir $90 \%$ peserta antusias dalam melaksanakan pelatihan

3. $60 \%$ peserta belum melaksanakan pembelajaran secara aktif, inovatif, kreatif, efektif dan menyenangkan

4. $50 \%$ peserta dalam membuka pelajaran belum melaksanakan kegiatan motivasi dan jarang melakukan ice breaking

\section{KESIMPULAN}

Berdasarkan seluruh uraian pemaparan laporan Program Kemitraan Masyarakat ini, maka dapat disimpulkan bahwa

1) Adanya sambutan dan antusiasme peserta yang tinggi selama mengikuti Program Kemitraan Masyarakat berupa kegiatan workshop. Hal ini diketahui dari hasil observasi dan penyebaran kuisioner selama kegiatan berlangsung.

2) Ketercapaian tujuan program, yakni peningkatan kemampuan mitra dalam melakukan pengembangan program pembelajaran anak-usia dini serta Manfaat yang diperoleh peserta dan lembaga juga menunjukan hasil yang positif.

\section{REFERENSI}

[1] Marzano, Robert J. 1992. A Different
Kind of Classroom, Teaching with Dimensions of Learning. Alexandria : ASCD

[2] Bruner, Jerome S., (1960), The Process of Education. Harvard University Press, London.

[3] Kementrian Pendidikan dan Kebudayaan, 2013)

[4] Undang-Undang Nomor 20 Tahun 2003 tentang Sistem Pendidikan Nasional).

[5] Permendiknas no 137 Tahun 2014 